\title{
Multiple sclerosis in the Republic of San Marino
}

\author{
G MORGANTI, ${ }^{1}$ S NACCARATO, ${ }^{1}$ M ELIAN, ${ }^{2}$ P FERRARI, ${ }^{3}$ R KELLY, ${ }^{4}$ \\ L KARHAUSEN, ${ }^{5}$ AND G DEAN ${ }^{6}$
}

From the Ospedale Nuovo, ${ }^{1}$ San Marino, Oldchurch Hospital, ${ }^{2}$ Romford, UK, Istituto di Scienze Sanitarie Applicate, ${ }^{3}$ Pavia, Italy, St Thomas's Hospital, ${ }^{4}$ London, UK, Commission of the European Communities, ${ }^{5}$ Luxembourg, and the Medico-Social Research Board, ${ }^{6}$ Dublin, Eire

SUMMARY Previous studies on the prevalence of multiple sclerosis in Italy have grossly underestimated the prevalence of the disease. The prevalence in the Republic of San Marino (near Rimini), in Sicily, and no doubt in the rest of Italy, is of the same order of magnitude as in Europe-that is, 40-60/100 000. The contrast of this with the very low prevalence in Malta (only 60 miles $(96 \mathrm{~km})$ away from Sicily) of $4 / 100000$ should provide a clue to the genetic and environmental factors responsible for multiple sclerosis.

In the past it has been reported that there is a gradient in the prevalence of multiple sclerosis from northern to southern Europe. ${ }^{1}$ Several studies of the prevalence of multiple sclerosis in Italy and Sicily ${ }^{2-4}$ confirmed a low prevalence of between four and $19 / 100000$ in contrast to a prevalence reported from middle and northern Europe of 40-60/100 000 . Among immigrants from Italy resident in Greater London, however, the risk of being admitted to hospital with a diagnosis of multiple sclerosis was not significantly different to the risk in the United Kingdom. The risk was also relatively high in the Greek and Turkish immigrants from Cyprus and the immigrants from Spain although not as high as in those born in the United Kingdom (table 1). ${ }^{5}$ In contrast to the Italian, Cypriot, and Spanish immigrants no Maltese patient with multiple sclerosis was in hospital in Greater London or in the West Midlands, although $10(9.7)$ would have been expected at the United Kingdom born rates. ${ }^{56}$

The high risk of being in hospital with multiple sclerosis among Italian born residents in Greater London and the absence of those born in Malta prompted studies to ascertain the prevalence of multiple sclerosis in Malta and in small cities in neighbouring Sicily, where in the large populations of Palermo and Messina the prevalence of multiple sclerosis had previously been reported to be low. ${ }^{34}$ Enna city in central Sicily was chosen for the first study and a high prevalence for probable multiple sclerosis of 53/100 000 was found. ${ }^{78}$ Studies in two other small cities of Sicily have confirmed a high prevalence. ${ }^{910}$ The mean prevalence of probable multiple sclerosis for the three cities studied in Sicily was $41 / 100000$ (table 2 ). In contrast, the prevalence in Malta was indeed low 4/100 000.11

If the prevalence has been seriously underestimated in Sicily it has probably been so in the rest of Italy. The Republic of San Marino presented an opportunity to ascertain the prevalence of multiple sclerosis in a small population with an excellent medical service.

\section{Method}

The Republic of San Marino is the smallest independent state in the world $\left(60.6 \mathrm{~km}^{2}(23.2\right.$

Table 1 Hospital first admissions for immigrants from Europe with multiple sclerosis resident in Greater London 1960-72

\begin{tabular}{|c|c|c|c|c|}
\hline & Male & Female & Total & $\begin{array}{l}\text { Expected number } \\
\text { at } U K \text { born rates }\end{array}$ \\
\hline \multicolumn{5}{|c|}{ North and Central Europe } \\
\hline Germany & 3 & 31 & 34 & $29 \cdot 2$ \\
\hline Poland & 18 & 7 & 25 & $25 \cdot 4$ \\
\hline Austria & 1 & 8 & 9 & $11 \cdot 0$ \\
\hline France & 4 & 7 & 11 & $9 \cdot 8$ \\
\hline Belgium/Luxembourg & 0 & 2 & 2 & 3.9 \\
\hline Netherlands & 1 & 2 & 3 & $4 \cdot 3$ \\
\hline Hungary & 3 & 4 & 7 & $6 \cdot 1$ \\
\hline Other & 8 & 21 & 29 & $24 \cdot 8$ \\
\hline Total & 38 & 82 & 120 & $114 \cdot 5$ \\
\hline \multicolumn{5}{|c|}{ Southern Europe } \\
\hline Italy & 12 & 12 & 24 & $27 \cdot 2$ \\
\hline Spain & $\mathbf{0}$ & 8 & 8 & $16 \cdot 4$ \\
\hline Cyprus* & 11 & 12 & 23 & $35 \cdot 0$ \\
\hline Malta & 0 & 0 & 0 & $8 \cdot 4$ \\
\hline \multicolumn{5}{|c|}{ Resident London and Birmingham } \\
\hline Malta & 0 & $\mathbf{0}$ & 0 & 9.7 \\
\hline
\end{tabular}


Table 2 Prevalence of probable multiple sclerosis in three cities in Sicily

\begin{tabular}{|c|c|c|c|c|c|c|}
\hline \multirow[b]{2}{*}{ Cities } & \multirow[b]{2}{*}{ Prevalence day } & \multirow[b]{2}{*}{ Population } & \multicolumn{4}{|c|}{ Probable multiple sclerosis } \\
\hline & & & Male & Female & Total & Rate/100 000 \\
\hline $\begin{array}{l}\text { Enna }^{7} \\
\text { Monreale }^{0} \\
\text { Agrigento }^{10}\end{array}$ & $\begin{array}{l}1 \text { January } 1975 \\
30 \text { June } 1980 \\
1 \text { January } 1975\end{array}$ & $\begin{array}{l}28189(1976) \\
25403(1980) \\
49979(1976)\end{array}$ & $\begin{array}{l}3 \\
6 \\
7\end{array}$ & $\begin{array}{r}12 \\
5 \\
9\end{array}$ & $\begin{array}{l}15 \\
11 \\
16\end{array}$ & $\begin{array}{l}53 \cdot 2 \\
43 \cdot 3 \\
32 \cdot 0\end{array}$ \\
\hline Total & & 103571 & 16 & 26 & 42 & $40 \cdot 6$ \\
\hline
\end{tabular}

sq $\mathrm{m})$ ) and is dominated by Mount Titano $(750 \mathrm{~m}$ $(2460 \mathrm{ft})$ above sea level). Most of the population live in San Marino town on Mount Titano or in eight small villages. The Republic is $22 \mathrm{~km}(14 \mathrm{~m})$ from Rimini between the Italian regions Marche and Romagna. The population at 31 December 1979 was 21322 (M 10683 , F 10639 ) of whom 18323 were Sammarinese citizens and the remaining 2999 mostly Italians. It is extremely difficult to obtain San Marino citizenship as Sammarinese have many advantages such as low taxation and excellent health and social services. There is a new and modern hospital and medical and social services records are well kept. San Marino presents therefore an ideal population for epidemiological studies. We studied the records of all patients who had been admitted to the medical department of San Marino hospital for the previous 20 years to find those who might have been suffering from multiple sclerosis. The patients with a history suggestive of possible multiple sclerosis who were still alive were then examined.

All residents of San Marino are entitled to free medical services whether they receive these services in San Marino or if they consult doctors elsewhere in Europe. Because patients avail themselves of these free services, which are well documented when their bills are paid by the San Marino State services, records are available not only for those who have been seen in San Marino but of those who consulted doctors elsewhere. We also asked each patient with multiple sclerosis whom we saw whether they knew of anyone else in San Marino with the disease.

We were concerned that there might be some sufferers who had not been seen by a doctor either in general practice or at the San Marino hospital for many years and who were not recorded in any of the San Marino health service records. We therefore searched the records of the neurological clinics in the neighbouring cities for the previous 30 years looking for any patients with possible multiple sclerosis who were resident in San Marino. The cities included Bologna, Modena, Ravenna, Ferrara, Forli, Ancona, and the Centro Studi Sclerosi Multipla at Gallerate. All the patients were examined by Sammarinese and Italian and also by non-Italian neurologists.

San Marino has an excellent pension scheme for the disabled. The records of all residents who were receiving disability pensions were studied to find if any of the disabilities suggested a diagnosis of multiple sclerosis.

\section{Results}

Tables 3 and 4 show in an abbreviated form the history and clinical findings of probable and possible sufferers resident in San Marino. There were, on prevalence day 30 June 1982, 11 probable patients, three men and eight women, and three possible patients, all women.

Three patients with probable multiple sclerosis were not recorded in any of the records systems of the hospitals or pension schemes in San Marino. Oneo patient was discovered accidentally by another patient who visited her house while crusading as a Jehovah's Witness (woman 6, table 3). Two further patients were found in the records of the neurologyo department at Bologna University who had been diagnosed in 1956 and 1954 respectively and they are of special interest (women 7 and 8 , table 3 ).

One woman (No 7, table 3) was admitted to the neurological clinic at Bologna University in 1956 with weakness in both legs, paraesthesia, and a feeling of constriction of the abdomen. She had weakness of the right side of the face, spastic weak legs, and extensor plantar responses. The Wasserman reaction test result was negative and the cerebrospinal fluid was normal. Mielopatia discresica was diagnosed. We visited her at her home in San Marino. She had been unable to walk since 1976 and was well looked after by her family. From her history and the clinical findings there is no doubt that she is suffering from probable multiple sclerosis. She had not been seen at San Marino hospital. The second patient found from the records system at Bologna (case 8) was admitted to the neurology clinic in 1954 complaining of blurring of vision and unsteadiness in her legs. The blurring of vision had improved and was then followed by weakness in her legs. She was diagnosed in Bologna in 1954 as suffering from multiple sclerosis. Confined to a bed to chair existence since 1960 she had not left her home since then. She was well looked after by her sons. Again, she had never attended a local hospital.

Despite searching for patients with multiple 
Table 3 Probable number of patients with Multiple Sclerosis resident in San Marino 31 December 1982

\begin{tabular}{|c|c|c|c|c|c|c|}
\hline No & Age & Date and 1st symptom & Remission & $\begin{array}{c}\text { Men } \\
\text { Relapse }\end{array}$ & Remission & Examination \\
\hline & \multirow{5}{*}{$\begin{array}{l}31 \\
6 \text { June } 51 \\
\text { Sammarinese }\end{array}$} & \multirow[t]{5}{*}{$\begin{array}{l}\text { Jul } 76 \text { Paraesthesia R } \\
\text { face. Diplopia }\end{array}$} & \multirow[t]{5}{*}{ Yes } & $\begin{array}{l}31 \text { May } 77 . \text { Weakness; } \\
\text { paraesthesia left arm }\end{array}$ & Yes & Tendon reflexes brisk $L>R$ \\
\hline & & & & $\begin{array}{l}6 \text { June } 78 . \quad \text { Paraesthesia of } \\
\text { abdomen }\end{array}$ & Yes & Ataxia left arm \\
\hline \multirow{3}{*}{1} & & & & $\begin{array}{l}7 \text { May } 79 . \text { Relapse Switzerland; } \\
\text { Bologna hospital; difficulty in } \\
\text { starting micturition }\end{array}$ & Yes & $\begin{array}{l}\text { Dysdiadochokinesia; weak R } \\
\text { leg; R Babinski equivocal; } \\
\text { spastic R leg }\end{array}$ \\
\hline & & & & $\begin{array}{l}5 \text { May } 80 \text {. Unsteady and weak } \\
\text { gait; improved again }\end{array}$ & Yes & \\
\hline & & & & $\begin{array}{l}30 \text { May } 81 \text {. Relapse, severe } \\
\text { weakness and ataxia of legs }\end{array}$ & & $\begin{array}{l}\text { Nystagmus; spastic } R \text { leg; ataxia; } \\
\text { plantar response } \uparrow \text { equivocal } \\
\text { left }\end{array}$ \\
\hline 2 & $\begin{array}{l}26 \\
19 \text { Jul } 56 \\
\text { Sammarinese }\end{array}$ & $\begin{array}{l}24 \text { June } 76 \text { Blurring } \\
\text { vision both eyes }\end{array}$ & Yes & $\begin{array}{l}1976 \text { Paraesthesia R leg } \\
1977 \text { Diplopia; difficulty in starting } \\
\text { micturition }\end{array}$ & Yes & $\begin{array}{l}\text { Nystagmus; pallor } L \text { disk; } \\
\text { plantar response equivocal }\end{array}$ \\
\hline 3 & $\begin{array}{l}31 \\
21 \text { June } 51 \\
\text { Sammarinese }\end{array}$ & \multicolumn{2}{|c|}{$\begin{array}{l}\text { March } 82 \text {. Hyperaesthesia Yes } \\
\text { followed by weakness L leg; } \\
\text { increased over } 15 \text { days until } \\
\text { unable to move leg. } \\
\text { Followed by paralysis } R \text { leg. } \\
\text { Urinary retention }\end{array}$} & $\begin{array}{l}\text { Recovered and after } 4 \text { months could } \\
\text { walk with a stick and after } 6 \text { months } \\
\text { walked unaided; Sept } 1982 \\
\text { paraethesia and weakness right } \\
\text { hand with return of leg weakness; } \\
\text { recovered after a few days; balance } \\
\text { remains impaired }\end{array}$ & Yes & $\begin{array}{l}\text { Leg tone increased; some } \\
\text { weakness; reflexes }+++\mathrm{L}>\mathrm{R} \\
\text { clonus ankles; plantar response } \\
\uparrow \uparrow ; \text {; abdominal reflexes } \\
\text { absent; CSF oligoclonal bands }\end{array}$ \\
\hline \multirow[t]{4}{*}{1} & \multirow{4}{*}{$\begin{array}{l}45 \\
25 \text { Jul } 37 \\
\text { English } \\
\text { married } \\
\text { Sammarinese } \\
\text { (Lived in San } \\
\text { Marino since } \\
1960 \text { ) }\end{array}$} & \multirow[t]{4}{*}{ Jan 1970 Diplopia } & \multirow[t]{4}{*}{ Yes } & \multicolumn{2}{|l|}{$\begin{array}{l}1970 \text { Weakness } R \text { leg and two } \\
\text { weeks later } L \text { leg; paraethesia } \\
\text { fingers \& hands; relapse, weakness } \\
\text { of legs a few months later }\end{array}$} & \\
\hline & & & & \multicolumn{3}{|l|}{$\begin{array}{l}1972 \text { Clonus } L \text { leg, worse in cold } \\
\text { weather }\end{array}$} \\
\hline & & & & 1977 Weakness L face & & \\
\hline & & & & 1981 Walks with aid only & & $\begin{array}{l}\text { Nystagmus; ataxia of arms; } \\
\text { spastic weak legs; plantar } \\
\text { response } \uparrow \uparrow\end{array}$ \\
\hline \multirow[t]{3}{*}{2} & \multirow[t]{3}{*}{$\begin{array}{l}32 \\
\text { Born } 1950 \\
\text { Sammarinese }\end{array}$} & \multirow[t]{3}{*}{$\begin{array}{l}1967 \text { Aged }+/-17 \text { years. } \\
\text { Paraesthesia face }\end{array}$} & \multirow[t]{3}{*}{ Yes } & $\begin{array}{l}1969 \text { Diplopia } 2 \text { weeks; weakness } \\
\text { both legs; urinary difficulty; ataxia of } \\
\text { arms }\end{array}$ & Yes & \\
\hline & & & & $\begin{array}{l}1979 \text { Relapse; unsteady arms and } \\
\text { legs }\end{array}$ & & $\begin{array}{l}\text { Ataxia, titubation of head; } \\
\text { nystagmus; spastic legs; clonus } \\
\text { ankles and knees; plantar }\end{array}$ \\
\hline & & & & 1981 Relapsed again & & $\begin{array}{l}\text { response 临; vibration sense } \\
\text { absent in legs }\end{array}$ \\
\hline \multirow[t]{4}{*}{3} & \multirow{4}{*}{$\begin{array}{l}49 \\
24 \text { Aug } 33 \\
\text { Sammarinese }\end{array}$} & \multirow[t]{4}{*}{$\begin{array}{l}1953 \text { Paraesthesia left } \\
\text { leg; vertigo }\end{array}$} & \multirow[t]{4}{*}{ Yes } & 1955 Relapse same symptoms & Yes & \\
\hline & & & & $\begin{array}{l}1956 \text { Relapse; weakness in both } \\
\text { legs }\end{array}$ & & $\begin{array}{l}\text { Paraparesis; tendon reflexes } \\
+++; \text { plantar response } \mathcal{A F}^{\prime} \\
\text { pallor of both fundi }\end{array}$ \\
\hline & & & & 1962 Deteriorated gait & & $\begin{array}{l}\text { Spastic paraparesis; nystagmus; } \\
\text { ataxia of arms; pallor both disks }\end{array}$ \\
\hline & & & & $\begin{array}{l}1970 \text { No longer able to walk; } \\
\text { ataxia of arms severe; married an } \\
\text { epileptic; sphincter problems }\end{array}$ & & $\begin{array}{l}\text { Decubitus ulcers; scanning } \\
\text { speech; nystagmus; ataxia; } \\
\text { spastic paralysed legs; } \\
\text { vibration sense absent in legs }\end{array}$ \\
\hline
\end{tabular}


Table 3 Probable number of patients with multiple sclerosis resident in San Marino 31 December 1982

-continued

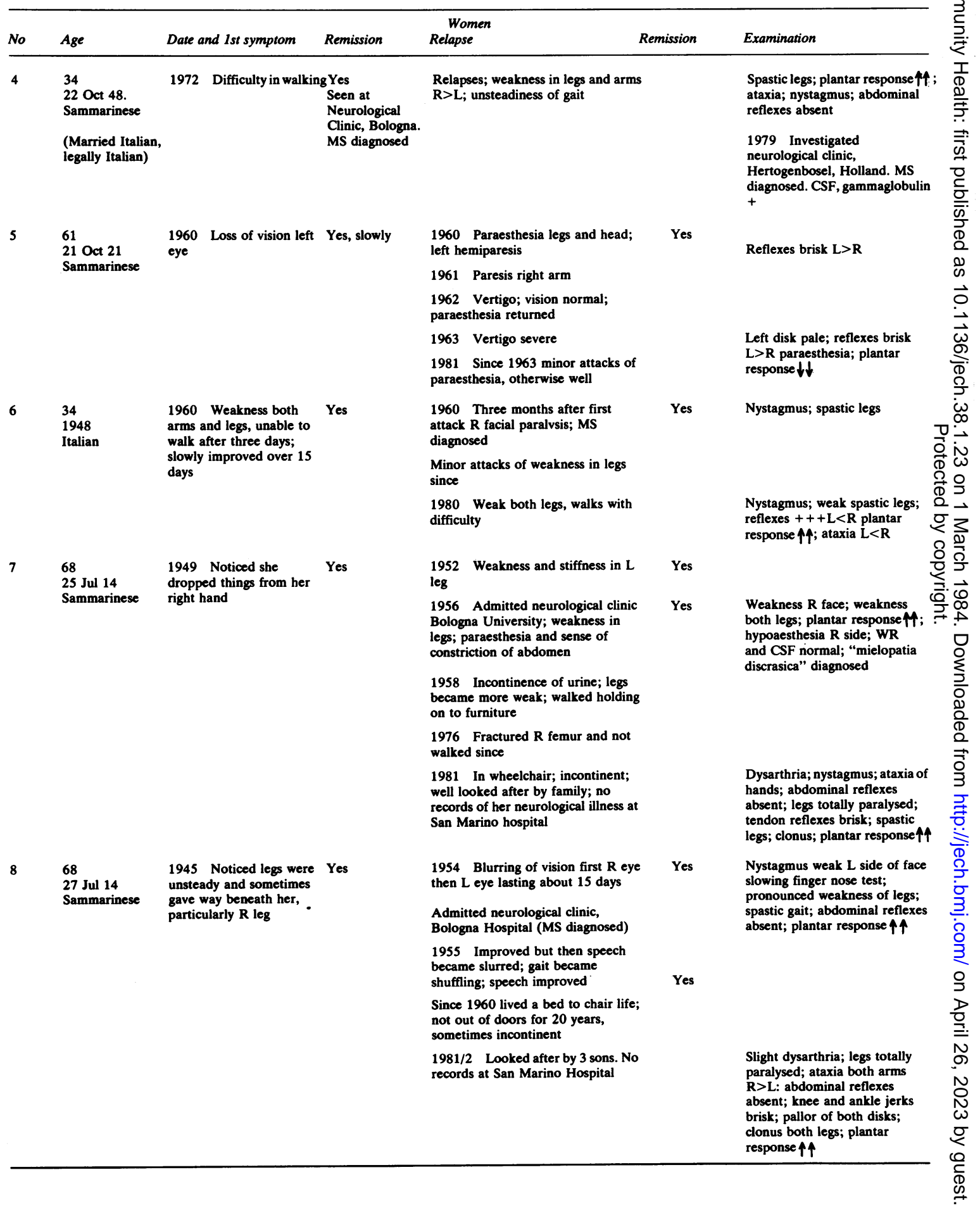


Table 4 Possible number of patients with multiple sclerosis resident in San Marino 31 December 1982

\begin{tabular}{|c|c|c|c|c|c|}
\hline No & Age & Date and 1st symptom & Relapse & Remission & Examination \\
\hline 1 & $\begin{array}{l}43 \\
6 \text { Apr } 39 \\
\text { Sammarinese }\end{array}$ & $\begin{array}{l}1969 \text { Vertigo; } \\
\text { paraesthesia } R \text { side of body; } \\
\text { pain } R \text { arm and lumbar } \\
\text { region; improved after } \\
x \text { ray treatment to neck; } \\
\text { syringomyelia suspected }\end{array}$ & $\begin{array}{l}1981 \text { says sometimes diplopia } \\
\text { looking L; whole story vague }\end{array}$ & & $\begin{array}{l}\text { Mild vertical nystagmus } \\
\text { hypoaesthesia } R \text { side of body; } \\
\text { brain scan normal; pandy }+/- \\
\text { VER normal }\end{array}$ \\
\hline \multirow[t]{3}{*}{2} & $\begin{array}{l}33 \\
22 \text { May } 49 \\
\text { Sammarinese }\end{array}$ & $\begin{array}{l}1972 \text { Noticed dilated } R \text { Yes } \\
\text { pupil }\end{array}$ & $\begin{array}{l}1975 \text { Pain diminished strength } R \\
\text { arm; weakness } R \text { leg; had to stop } \\
\text { driving car }\end{array}$ & Yes & \\
\hline & & & $\begin{array}{l}1977 \text { Loss of sensation in hands; } \\
\text { pain in neck; complained of loss of } \\
\text { strength in arms }\end{array}$ & & Anisocoria $\mathbf{R}>\mathbf{L}$ \\
\hline & & & $\begin{array}{l}1981 \text { No objective symptoms or } \\
\text { signs }\end{array}$ & & Refuses VER test \\
\hline 3 & $\begin{array}{l}30 \\
2 \text { Nov } 52 \\
\text { Sammarinese }\end{array}$ & $\begin{array}{l}1979 \text { "Heaviness" of bothYes } \\
\text { legs; great difficulty in } \\
\text { walking because of } \\
\text { weakness in legs; lasted } \\
\text { one month }\end{array}$ & $\begin{array}{l}\text { June } 1982 \text {. A strange sensation "hot } \\
\text { and cold" in both legs below knees } \\
\text { for one month; Oct } 1982 \text {. Vertigo } \\
\text { and unsteady gait followed by } \\
\text { diplopia for } 10 \text { days and lack of taste } \\
\text { in tongue; followed by urinary } \\
\text { frequency }\end{array}$ & Yes & $\begin{array}{l}\text { Unsustained nystagmus; fundi, } \\
\text { normal; some weakness L leg; } \\
\text { deep tendon reflexes brisk; } \\
\text { plantar response L equivocal, } R \\
\text { flexor lower abdominal reflexes } \\
\text { absent; no ataxia; CSF no } \\
\text { abnormality found; VER } \\
\text { normal }\end{array}$ \\
\hline
\end{tabular}

VER $=$ Visual evoked response

sclerosis for three years, there may be more patients in San Marino who have not yet been traced or perhaps diagnosed. Repeated studies in other areas have found a higher prevalence of multiple sclerosis than earlier studies. Calculating the prevalence on 11 patients in a population of 21322 , the prevalence of probable multiple sclerosis among the residents of San Marino is 52 per $100000(51 \cdot 6)$, (28.1 per 100000 male, $75 \cdot 2$ per 100000 female). If possible and probable patients are included, the prevalence is 65.7 per 100000 . The prevalence in San Marino is similar to that found in Sicily and in other studies in northern Europe. Prevalence studies in small populations are bound to vary considerably by chance, and in San Marino there is a much higher prevalence for woman than for men. In Enna also there was a higher proportion of women than men than is found in most studies, where the usual ratio is 3:2 but when the three small cities studied in Sicily are taken together the ratio was also approximately $3: 2$ (3.2:2) (table 2).

In searching for patients with possible multiple sclerosis several other interesting disorders were seen-for instance, a young man who in January 1974 had been bitten by a dog that was thought to have rabies. He was given a course of antirabies injections and after seven injections he developed paraesthesia and weakness in the legs. There was hyper-reflexia, greater on the right side than on the left, clonus of the right foot, the right plantar response was extensor, and the abdominal reflexes were absent. He slowly improved but he still has weakness in his legs.

\section{Conclusion}

Previous studies on the prevalence of multiple sclerosis in Italy grossly underestimated the prevalence of the disease. In three cities in Sicily and in the Republic of San Marino recent studies show that the prevalence of multiple sclerosis in San Marino and Sicily is of the same order of magnitude as has been reported in other studies in Europe, that is $40-60 / 100000$. These findings are supported by the risk of developing multiple sclerosis in Italian immigrants in London. Other recent studies in Copparo,12 Trento (G Kossi et al, personal communication), and Beddagho, Sardinia, ${ }^{13}$ have also shown a similar high prevalence. The high prevalence in San Marino and in Sicily and, no doubt, in the rest of Italy, contrasts with the very low prevalence, $4 / 100000$ found in the islands of Malta only 60 miles $(96 \mathrm{~km})$ from Sicily. This sudden rather than gradual fall in the prevalence of multiple sclerosis between Sicily and Malta should provide a clue to the genetic and environmental factors responsible for the syndrome.

We thank Signora Franca Montanari, San Marino, and Professor A Marinoni and Professor E Torre, Pavia. We also thank the neurologists and the staff of the neurology records departments at the hospitals of Bologna, Modena, Ferrara, Ravenna, Forli, and Ancona and also the Centro Studi Sclerosi Multipla, Gallarate. Finally, we thank the patients who 
collaborated with us in this study.

This research was supported in part by the Commission of the European Communities and the Committees of Medical Research and Public Health.

\section{References}

${ }^{1}$ McAlpine D, Lumsden CE, Acheson EC. Multiple sclerosis: a reappraisal. 2nd ed. London: Churchill Livingstone, 1972.

${ }^{2}$ Borri P, Tavolato V, Ballatari E, Cazzullo C. Epidemiological survey on multiple sclerosis in Italy. Riv Patol Nerv Ment 1976: 97: 205-10.

${ }^{3}$ Savettieri G, Piccoli F, Chiaravalle E, et al. Epidemiological survey on multiple sclerosis in the city of Palermo (Italy). Acta Neurol 1978: 33: 526-31.

- Bramanti P, Messina C, Scuderi D, Vita G. An epidemiological study of multiple sclerosis in the province of Messina. Acta Neurol 1978; 33: 532-9.

${ }^{5}$ Dean G, McLoughlin H, Brady R, Adelstein AM, TallettWilliams J. Multiple sclerosis among immigrants in Greater London. Br Med J 1976; i; 861-4.
${ }^{6}$ Dean G, Brady R, McLoughlin H, Elian M, Adelstein AM. Motor neurone disease and multiple sclerosis among immigrants to Britain. British Journal of Preventive and Social Medicine 1977; 31: 141-7.

${ }^{7}$ Dean G, Grimaldi G, Kelly R, Karhausen L. Multiple sclerosis in southern Europe I: Prevalence in Sicily 1975. J Epidemiol Community Health 1979; 33: 10710.

${ }^{8}$ Grimaldi G. Esperienze sulla sclerosi multipla in Sicilia. Atti 111 Convegno Nazionale di Neuroepidemiologia. Milan: Societa Italiana di Neurologia 1982.

${ }^{9}$ Savettieri G, Daricello B, Giordano D, Karhausen L, Dean G. The prevalence of multiple sclerosis in Sicily I: Monreale city. J Epidemiol Community Health 1981: 35: 114-7.

${ }^{10}$ Dean G, Savettieri G, Giordano D. et al. The prevalence of multiple sclerosis in Sicily II: Agrigento city. $J$ Epidemiol Communty Health 1981; 35: 118-22.

${ }^{11}$ Vassallo L, Elian M, Dean G. Multiple sclerosis in southern Europe. II: Prevalence in Malta in 1978. J Epidemiol Community Health 1979; 33: 111-13.

${ }^{12}$ Rosati G, Granieri E, Cárrerras M, Tola R. Multiple sclerosis in southern Europe: a prevalence study in the sociosanitary district of Copparo, northern Italy. Acta Neurol Scand 1980: 62: 244-9.

${ }^{13}$ Rosati G, Pinna L, Granieri E, et al. The distribution of multiple sclerosis in Sardinia. Riv Patol Nerv Ment 1977; 98; 46-64. 